\title{
English Expressions in Tourism promotion Media of Solo Raya, Indonesia
}

\author{
Agus Hari Wibowo \\ Universitas Sebelas Maret \\ Diah Kristina \\ Universitas Sebelas Maret \\ Azilah Kasim \\ Universiti Utara Malaysia
}

\begin{abstract}
Communicating a destination's unique tourism products and offerrings to the international market requires strong grasp of the shared language. This however can be a great challenge in a non English speaking country. This paper discusses the effectiveness of the use of English in tourism promotion media in Solo Raya regions. The objectives of the research are to: (1) identify use of English in tourism promotion media of Solo Raya; (2) explore the persuasive elements in tourism promotion media of Solo Raya; (3)analyze the effectiveness of the expressions used in tourism media, and (4) propose a model of persuasive language. This research is a qualitative descriptive study. The data is collected using several methods, i.e., content analysis, observation, focus group discussions, and interviews. The results show that 1) the Solo Raya tourism promotion media use more descriptive expressions in their contents, 2) elements of persuasion are rarely used in tourism promotion media, 3) the language of tourism promotion has not been effective, and 4) model of persuasive language promotion can be realized in the form imperative and questions.
\end{abstract}

Keywords: media, tourism, promotion, Solo Raya, Indonesia.

\section{INTRODUCTION}

In recent years, tourism has been significantly dependent on online media such as the internet. This is not surprising because the rapid development of sufficient information is parallel with the development of the movement of people, power, and money. Historically, global electronic network was actually initiated by the travel industry, including the tourism industry. This occurred long before the internet emerged (Hasbrouck, 2001).

In the world of tourism, internet is used to promote a wide range of issues related to such tourism products as promotion to the tourist attraction. In Solo Raya regions, tourism has been promoted through various media, including online media such as websites on the internet. Thus, the existence of the website has an important role to sell the attractions or tourist attraction. Promotional messages should be delivered by using appropriate language, i.e., the expressions that can achieve the promotional purposes.

As the main stakeholder of tourism, the Indonesian government should actively promote tourist destinations through online media in English in order to attract foreign tourists. In line with the target of the Indonesian Government to increase the number of international tourist arrivals to as many as 7 million people in 2014, efforts are needed to promote the country's tourist attractions to foreign tourists. As English is long considered an international language, the promotion should use English and have a persuasive power that makes tourists interested to visit tourist destinations in Indonesia, including the Solo Raya region (Kemenparekraf, 2013). Compared to Malaysia, however, the Indonesian government isn't very concerned with the development of tourism, including the importance of using an online campaign to boost the number of tourist visits.

As the primary media promotional outlet of tourism, the tourism websites of the Solo Raya region need to be built using appropriate English in order to convey promotional messages effectively. Language has an important role in promoting tourism attraction in order to foster the interest of 
tourists to visit such attraction. The language used in any promotional effort should employ persuasive language that is able to persuade customers or tourists to come to the promoted destinations.

\section{Literature REVIEW}

\subsection{Language and Tourism}

According to Dann (1996) the relationship between language and tourism can be seen from at least four theoretical approaches, i.e., authenticity, strangerhood, play, and conflict. Perspective of authenticity is basically initiated by MacCannell (1989), concerning the authenticity of a tourist attraction associated with semiotic elements. According to tourist attraction, it is a sign that marks something to someone (tourist). Marker functions to provide information such as the name or picture of a sight. Marker can be off-sight such as travel books or stories submitted by people who have ever visited tourist attraction, and may also be on-sight such as notices contained in the tourist locations. Markers can also be regarded as a symbol that represents an object, place, or a tourist attraction. For example, in the field of tourism, Barong, Kecak dances represent Bali, Asmad statue represents Papua, and so forth.

Perspective of strangerhood refers to the theory presented by Cohen (1972) which states that "the novelty and strangeness constituted essential elements in the touristic experience, and that they were hence primary motives for tourism." However, not all travelers are looking for things that are really new and strange. Among the tourists who travel, there are tourists who are always trying to find a familiar atmosphere so that they will feel at home, especially when they need a place to stay, to eat, and the like. Therefore, in the context of this stranger hood there is a continuum that starts from the leftmost point where there are things that are very familiar to tourists until the rightmost point where there are things that are very unfamiliar or new to the tourists. Things that are familiar to tourists are usually sought after by tourists classified as organized as mass tourists. While things that are alien or new to the tourists are usually sought after by tourists group called drifters and wanderers who want the adventure to find things that are new and they have never known before. They are also called as novelty seekers.

The next perspective is play, where tourists visiting a site or tourist attraction are welcome or given the opportunity to play in accordance with the typical local games offered so that they can learn the culture and character of the local people directly. This is intended to enrich the experience of tourists visiting tourist sites that offer the unique game to tourists.

The last perspective is a conflict. This perspective starts from the approach made by the humanists and scientists. The perspective of conflict is different from the other three perspectives. Conflict refers to two things that are mutually opposed. In the context of tourism, two opposite things are those that have a significantly different character, such as between East communities (the Orientals) and Western societies (the Westerners). Said (1991) in Dann (1996: 24) states "This discourse is essentially about power (political, intellectual, cultural, and moral) and the unequal distribution of knowledge into texts. Since Orientals are judged to be incapable of speaking for themselves, they are represented as familiar through external narratives which display little concern for the truth. A textual dualism thus emerges in which the Oriental is portrayed as 'irrational, depraved, childlike and different' while the Western author is seen as 'rational, virtuous, mature and normal. The world is similarly separated between the familiar and the strange, between our territory and theirs, between the powerful and articulate and the defeated and distant."

\subsection{Language of Tourism Promotion}

Language of promotion cannot be separated from the utilization of diction, construction phrase, clause, sentence, the utilization stage of rhetorical (rhetorical staging), expression pattern, and markers of discourse (Swales, 1990, 2000; Bhatia, 1993, 2004; Kristina. 2011, 2014) in addition to other sources such as drawings, illustrations, logos, maps, etc. All of the components mentioned should be used as the driving force (pragmatic force) so that readers or potential travelers are attracted, enticed and motivated to visit a tourist destination offered.

Seaton and Bennett (1996: 179) state that the promotion of tourism has the following specific objectives. Effective promotion starts, like any other marketing activity, from an analysis and clear formulation of strategic objectives. These involve: (1) identification of the target audiences to be 
reached; (2) identification of the communication goals to be achieved; (3) formulation of messages designed to achieve the goals; (4) choice of media for delivering the messages effectively to the target audiences; (5) allocation of a budget to achieve the production and delivery of the messages; and (6) evaluation mechanism in terms of sales.

Tourism promotion conducted by government agencies such as the Department of Culture and Tourism is usually in the form of procurement of printed media such as advertisements in newspapers, magazines, pocket books, booklets, leaflets, brochures, posters, flyers, procurement of electronic media such as advertising on television, radio, CD-ROM / VCD / DVD and a website on the Internet, as well as exhibitions, cultural missions (cultural mission), travel exchange, the travel mart, and road shows.

Online tourism promotion has some advantages because of the character of a 'multimodal', in the sense that it utilizes all sources of meaning in the form of language, images, music illustration, color, font selection, layout, logo, etc. (Kress \&Leeuwen, 2001; O'Hallorn, 2004; Kress, 2010). With the increasing number of internet users in Indonesia, online promotions become the backbone of the business as cost-effective as compared to the promotion through a sort of television and electronic media accessible to people around the world. However, online promotion has drawbacks because the space is limited. This can be circumvented through persuasive word choice, effective sentences and selection of illustrations or images that are relevant and interesting as an attention-getter.

\section{METHOD}

This is a descriptive study using under qualitative paradigm. This study was carried out in the regions of Solo Raya, namely the ex-Surakarta which include municipality and regencies of: Surakarta, Boyolali, Sukoharjo, Karanganyar, Wonogiri, Sragen and Klaten. The regions are areas with various tourist attractions that require proper promotion techniques, especially with the use of effective English for the promotion which is able to attract more visitors to come to tourist destinations in Solo Raya.

Sources of data in this study are information from informants, places and events as well as document printing and electronic (online / website) with regard to the promotion of tourism Solo Raya. In this study the informants consist of representatives of private, public and the government, particularly the Department of Culture and Tourism of Surakarta, Boyolali, Sukoharjo, Karanganyar, Wonogiri, Sragen and Klaten which have capacity of technically and organizationally planning development programs promotion of regional tourism, as well as all elements of society, particularly related to tourism development areas to increase the number of tourist visits to the region of Solo Raya.

Data are collected by observation method of the Solo Raya tourism promotion media (print and electronic), Focus Group Discussion, interview, and content analysis of the existing document study. Field notes, digital voice recorder, and camera are used to collect data.

The sampling technique used in this research is purposive sampling, more specifically snowballing. The selection of key informant is like a snowball rolling that is by collecting information from the key informants who know lots of the key issues to the next informant to meet the adequate data. The data analysis technique used in this research is interactive analysis by Miles \& Huberman (1984).

\section{RESUlTS AND DiscuSSION}

Our observation shows that while most tourism promotion media in Solo Raya use English, the online promotion sites in Indonesia are largely dominated by private institutions rather than public agencies. Consequently though they use English as a medium for communication, the content, presentation style, ideology, and its purpose are much influenced by the personal or institutional agenda of the creator of the online promotions.

To explore the persuasive elements in tourism promotion media of Solo Raya, we looked at the expressions of persuasive language in the texts of the promotion of tourism website, mainly in Solo Raya region. The results of the analysis showed that overall, the expressions of persuasive language in the texts are rarely used in promotion of tourism website. The results of text analysis (content analysis) as well as interviews with informants, a native speaker of English show that the texts of tourism promotion media in Solo Raya regions are not attention grabbing due to the mistakes and errors of the expression. The typical errors or mistakes can be seen in Table 1 . 
Table1. Typical Errors or Mistakes

\begin{tabular}{|c|c|c|}
\hline Types of Typical Errors & Examples of Errors/Mistakes & Revised Version \\
\hline $\begin{array}{l}\text { 1. Selection of word } \\
\text { class }\end{array}$ & $\begin{array}{l}* \text { The contains are sewed together with } \\
\text { sweet ginger. } \\
* \text { It is prehistorically museum. }\end{array}$ & $\begin{array}{l}\text { - The contents are sewed together } \\
\text { with sweet ginger. } \\
\text { - It is prehistorical museum. }\end{array}$ \\
\hline $\begin{array}{ll}\text { 2. } & \begin{array}{l}\text { Word selection } \\
\text { (diction) }\end{array}\end{array}$ & $\begin{array}{l}* \text { It is delicious and durable. } \\
* \text { It is made of cow's leather processed } \\
\text { into small cracker. }\end{array}$ & $\begin{array}{l}\text { - It is delicious and long shelf-life. } \\
\text { - It is made of cow's skin processed } \\
\text { into small cracker. }\end{array}$ \\
\hline $\begin{array}{l}\text { 4. incomplete sentences } \\
\text { (fragment) }\end{array}$ & $\begin{array}{l}\text { * Made of rice the which has been } \\
\text { cooked with chicken broth. } \\
* \text { Which is famous for its taste. }\end{array}$ & $\begin{array}{l}\text { - It is made of rice the which has } \\
\text { been cooked with chicken broth. } \\
\text { - ... which is famous for its taste. }\end{array}$ \\
\hline $\begin{array}{l}\text { 5. the absence of } \\
\text { subject and verb }\end{array}$ & * Sell & They sell sp \\
\hline 6. tense & $\begin{array}{l}\text { * Radya Pustaka Museum is one of the } \\
\text { old museum in Indonesia that is built } \\
\text { in } 1890 \text {. }\end{array}$ & $\begin{array}{l}\text { - Radya Pustaka Museum is one of } \\
\text { the old museums in Indonesia that } \\
\text { was built in } 1890\end{array}$ \\
\hline $\begin{array}{l}\text { 7. active and passive } \\
\text { sentences. }\end{array}$ & $\begin{array}{l}* \text { The gallery located in Slamet Riyadi } \\
\text { Street } 261 \text {, }\end{array}$ & $\begin{array}{l}\text { The gallery is located at Slamet } \\
\text { Riyadi Street } 26 .\end{array}$ \\
\hline 8. Preposition errors & $\begin{array}{l}\text { * The diamond contains of the } \\
\text { diamond, noodles, bean sprouts. * } \\
\text { Dawet Ayu Gede Market is different } \\
\text { than dawet sold anywhere. } \\
\text { * Pancake Solo is different with } \\
\text { common pancake is found in other } \\
\text { local towns. }\end{array}$ & $\begin{array}{l}\text { - The diamond contains the diamond, } \\
\text { noodles, bean sprouts. } \\
\text { Dawet Ayu Gede Market is different } \\
\text { from Dawet sold anywhere. } \\
\text { - Pancake Solo is different from } \\
\text { common pancake found in other } \\
\text { local town }\end{array}$ \\
\hline
\end{tabular}

Our analysis on the effectiveness of the expressions used in tourism media, also showed that there are many errors or mistakes taking place. Such grammatical features include word class, word choice, incomplete sentence, active and passive sentence, tense, and preposition. The mistakes or errors of the expressions are actually fatal as it makes the target readers, i.e., foreign tourists, find them difficult to understand.

In addition to error or mistakes, the pattern of expressions used in tourism media in Solo Raya is dominated by the use of an informative expression where the promotion writers rarely use the persuasive expressions. Some of pure informative sentences can be seen in the following examples:

Table2. Expression in Tourism Brochures

\begin{tabular}{|l|l|}
\hline No & \multicolumn{1}{|c|}{ Sentences } \\
\hline 1 & Laweyan is a central batik industry with the valuable historical values. \\
\hline 2 & Triwindhu market is located in Diponegoro street, Keprabon, Banjarsari, Solo. \\
\hline 3 & Kauman is an old village where developing together with the Solo city progress. \\
\hline 4 & $\begin{array}{l}\text { There really are many s good, why the Sriwedari Amusement Park stands out as a leading attraction in } \\
\text { Solo. }\end{array}$ \\
\hline 5 & $\begin{array}{l}\text { Whilst it is fair to say that Taru Jurug Animal Park will never be an award-winning zoo, this is a } \\
\text { pleasant enough attraction for families. }\end{array}$ \\
\hline 6 & $\begin{array}{l}\text { The Mosque of Surakarta in Solo is known locally as the Great Mosque and is located on the westerly } \\
\text { side of the Alun Alun area, off Jalan Secoyudan. }\end{array}$ \\
\hline 7 & $\begin{array}{l}\text { Standing alongside the Radya Pustaka Museum and next to the railway line, the Radya Pustaka } \\
\text { Museum contains a rather eclectic collection of objects, the which range from Indonesian jeweled } \\
\text { daggers (kris) and 'wayang puppets, to various antiquities and traditional musical instruments ( } \\
\text { gamelan). }\end{array}$ \\
\hline 8 & $\begin{array}{l}\text { The Sukuh is a magnificent Javanese-Hindu temple and is sandwiched between East Java and Central } \\
\text { Java. }\end{array}$ \\
\hline 9 & $\begin{array}{l}\text { Around } 50 \text { km / 31 miles from Solo and just 17 km / 11 miles from Yogyakarta, the Prambanan } \\
\text { temples are quite impressive and well connected by bus. }\end{array}$ \\
\hline 10 & $\begin{array}{l}\text { The hill resort of Tawangmangu stands on the westerly side of Lawu and has become something of a } \\
\text { popular weekend destination for locals in Solo. }\end{array}$ \\
\hline
\end{tabular}

The expression on the table 2 above shows that the writers only give information or description of the place or things without putting some persuasive expressions. Even some of the sentences are ungrammatical or confusing. This accordingly does not give impact to the readers or tourists to visit the sites. 
It can be concluded that the use of English in the media promotion has not been effective because some of the expressions are still difficult to be understood due to many errors in diction, and grammar, as well as the selection of a language that has not demonstrated persuasive language. Almost the entire texts contained in Solo Raya tourism websites are in the form of information text. This means that most of tourism texts in Solo Raya in the website do not use persuasive expressions purposed to persuade tourists to visit the tourist destinations.

Referring to the results of the above discussion, we would suggest a model of persuasive language that should be used in tourism promotion media.

Tabel3. The Suggested Model of Imperative Sentences

\begin{tabular}{|c|c|}
\hline Regions/Sites & Suggested models \\
\hline Surakarta & $\begin{array}{l}\text { - See some interesting attractions you would not see in other places! } \\
\text { - Enjoy yourselves watching the traditional dances in Keraton kasunanan Surakarta } \\
\text { every Wednesday night. } \\
\text { Meet some amazing artifacts used by the family of the Keraton in the past time in } \\
\text { Keraton Kasunanan Surakarta Museum! Some amazing artifacts here are } \\
\text { impossibly found in other countries. }\end{array}$ \\
\hline Wonogiri & $\begin{array}{l}\text { - Wanna see a great and beautiful of Gajah Mungkur Reservoir from the sky? Do } \\
\text { Hand Gliding, and you will see the whole of Gajah Mungkur Reservoir from } \\
\text { above! } \\
\text { - Enjoy your moment with your family } \\
\text { - Visit Gajah Mungkur Dam, the natural beauty of Wonogiri. Spend your time with } \\
\text { your family. You'll never regret! }\end{array}$ \\
\hline Cetho Temple & $\begin{array}{l}\text { - } \quad \text { Enjoy an adventure in the ancient town of Karanganyar } \\
\text { - } \quad \text { Visit cetho temple. Come to Cetho Temple and feel the fantastic journey! } \\
\text { - } \quad \text { Experience the exotic cultural heritage in Cetho temple }\end{array}$ \\
\hline Sukoharjo & $\begin{array}{l}\text { - Wondering what those instruments made of? How are the made? } \\
\text { - Go and get all your questions answered in Wirun Village! The center of gamelan } \\
\text { production. } \\
\text { What are you waiting for? Get here. Let's see and learn the secret of beautiful } \\
\text { sound of gamelan. }\end{array}$ \\
\hline Klaten & $\begin{array}{l}\text { - } \quad \text { Enter the great ancient Java! In Prambanan temple } \\
\text { - What are you waiting for? Come and enjoy it! } \\
\text { - } \quad \text { Come and see the extraordinary cultural heritage of Central Java! }\end{array}$ \\
\hline Sriwedari Park & $\begin{array}{l}\text { - } \quad \text { Enjoy your leisure with adventure! } \\
\text { - } \quad \text { Come to Sriwedari Amusement Park, and create an unforgettable moment! }\end{array}$ \\
\hline $\begin{array}{l}\text { Grojogan } \quad \text { Sewu } \\
\text { Waterfall }\end{array}$ & $\begin{array}{l}\text { - Let's go fresh our minds and relax your body } \\
\text { - Want to escape from the city's heat? Let's go and come to Grojogan Sewu } \\
\text { Waterfall }\end{array}$ \\
\hline
\end{tabular}

Table4. Suggested Model of Yes-No Questions

\begin{tabular}{|c|c|}
\hline Type of Expressions & Expression \\
\hline $\begin{array}{l}\text { Question (Yes- } \\
\text { No) }\end{array}$ & $\begin{array}{l}\text { - Disappointed with hotel? Stay with us in the traditional cottage. } \\
\text { - Wanna see a great and beautiful reservoir from the sky? Do Hand Gliding, and } \\
\text { you will see the whole corners of the reservoir from above! } \\
\text { - Want to escape from the city's heat? Come to the marvelous Waterfall. } \\
\text { - Wondering why gamelan sounds so beautifully? Wondering what those } \\
\text { instruments made of? Come to the center of gamelan workshop. }\end{array}$ \\
\hline
\end{tabular}

Table5. The suggested model of Wh-Word Questions

\begin{tabular}{|l|l|l|}
\hline Type of Expressions & \multicolumn{2}{|c|}{ Examples of Expression } \\
\hline Question (question- & $\bullet$ & Why don't you stay with us? Come, spend your night with the locals. \\
word question) & $\bullet \quad$ Why don't you enjoy the melodious traditional musical instrument? \\
& $\bullet \quad$ What are you waiting for? Come now. Enjoy and learn the secret of beautiful \\
& $\begin{array}{l}\text { - } \\
\text { sound of gamelan. }\end{array}$ \\
\hline
\end{tabular}

The suggested model might be the alternative to make the websites or brochures more interesting. The interesting or attractive promotion will attract the potential tourists to visit the destinations, which accordingly increase the number of visitors. 


\section{Conclusions}

From the study findings it is evident that the English expressions that are used in promotional materials to promote tourism in Solo Raya regions contain a lot of errors or mistakes, both in terms of grammar, word choice (diction), and cultural terms. These conditions may lead to lack of clarity and confusion among foreign visitors or tourists who are interested to learn about the destination through its promotional materials. Moreover, although more useful, writers of the Solo Raya regions have not utilized persuasive expressions to entice their target readers. To put it in another way, the expression language has not been effectively used to attract foreign tourists' attention, because English expressions employed to promote tourism in Solo Raya are mostly informative in nature, and not using persuasive expressions. Therefore it can be proposed that the writers of Solo Raya regions writers adopt persuasive expressions more effectively in future work so that the materials become more interesting to foreign tourists. They should employ persuasive expressions in the form of imperative sentences or questions either yes/no questions or wh-word questions so that the intended readers' attention can be sustained much longer.

Future study on this topic could attempt to understand the underlying reasons behind weaknesses in the Solo Raya regions' writers ability to write in a succinct, interesting and attention-grabbing manner. What causes the writers to have such weakness? What lead them to make such errors? How could local policy be shaed to address those causes? These are some useful research questions that could be explored. The knowledge generated could be useful to understand issues and problems of non-english speaking rural destinations around the world to market effectively to international tourists who largely use English for communication during travel.

\section{REFERENCES}

Bhatia, V., K. (2004). World of written discourse: a genre based view: Advances in applied linguistics. London: Sage Publication.

Bhatia, V.K. (1999). Integrating products, processes, purposes and participants in professional writing, in C.N. Candlin and K.Hayland (eds), Writing: Texts, Processes and Practices. London: Longman, 21-39.

Bhatia, V. K. (1993). Simplification versification: the case of legal texts. Applied Linguistics, 4/1, 4254.

Dann, G.(1996), The Language of Tourism: A sociolinguistic perspective, Wallingford: CAB International.

Dijk, T, A. van. (1997). Discourse as social interaction. Discourse studies: A multidisciplinary introduction Volume 2 (Ed). London: Sage Publication Ltd.

Eriyanto, (2001), Analisis wacana: pengantar analisis teks media, Yakarta: PT. Pelangi Aksara.

Hasbrouck, E.,(2001).The Practical Nomad: Guide to the online travel marketplace, Emeryville, USA: Avalon Travel Publishing.

Kathpalia, S. S. (1992). A genre analysis of promotional texts. $\mathrm{PhD}$ thesis submitted to the National University of Singapore.

Kristina, D. (2011). A genre analysis of sales promotion letters and company profiles in an Indonesian batik industry.Unpublished Dissertation.Universiti Utara Malaysia.

Kristina, D. (2011). Image building in English. Buku teks mengajar. Surakarta: Diploma 3 Bahasa Inggris. Fakultas Sastra dan Seni Rupa. Universitas Sebelas Maret.

Kristina, D. (2014). Building trust and credibility: The rhetoric of positive self image in the advertorials of Garuda Indonesia. Proceeding dalam Kongres Internasional Masyarakat Linguistik Indonesia. Bandar Lampung, 19-22 Pebruari 2014.

Kress, G. \& Leeuwen, T. V. (2001). Multimodal discourse: The modes and media of contemporary communication. New York: Oxford University Press Inc.

Kress, G. (2010). Multimodality: A social semiotic approach to contemporary communication. New York: Routledge.

Kvale, S. (1996). Interviews: an introduction to qualitative research interviewing. Dalam Rara Sugiarti. (1998). The potential for developing ecologically sustainable rural tourism in Surakarta, Central Java, Indonesia. A master thesis. James Cook University Australia. 
Lathifah, N. D, (2007), Analisis faktor-faktor yang mempengaruhi strategi adaptasi promosi ekspor bagi peningkatan kinerja pemasaran ekspor: studi kasus industri ekspor furniture di Jawa Tengah, Semarang: Universitas Diponegoro (Thesis), http://eprints.undip.ac.id/ 16992/1/ DIAN_NURUL_LATHIFAH.pdf

Limaye, M.R. (1984). The syntax of persuasion: Two business letters of request. Journal of Business Communication, 20/2, 17-30.

Miles, M. B. \& Huberman. A. M., (1984), Qualitative Data Analysis: A Sourcebook of New Methods. London: Sage Publications.

Novalina, L. (2008), Peranan promosi wisata di Dinas Kebudayaan dan Pariwisata Bandung dalam meningkatkan motivasi wisatawan terhadap Kota Bandung dan sekitarnya, Bandung: Universitas Widyatama.

http://repository.widyatama.ac.id/xmlui/bitstream/handle/123456789/2245/content.pdf?sequence=1

O’Hallorn, kay. L. (2004). Multimodal discourse analysis: systemic functional perspectives. London: Continuum.

Peta Kawasan Solo Raya, http://www.skyscrapercity.com/showthread.php?t=1500441

Rianto, Riki, dkk, Pengembangan sistem informasi promosi pariwisata pada Kota Payakumbuh dengan menggunakan bahasa pemrograman PHP berbasis MYSQL, http://www.upiyptk.ac.id/ejournal/File_Jurnal/09101152610536_Riki\%20Rianto_Sistem\%20Informasi.pdf

Seaton \& Bennett, 1996, Marketing tourism products: concepts, issues, cases, London: International Thomson Business Press.

Swales, J. M. (2000). 'Language for specific purposes'.Annual Review of Applied Linguistics, 20, 5976.

Swales, J. M. (1990).Genre analysis: English in academic and research settings. Cambridge: Cambridge University Press.

Wahab, S., (2003). Manajemen kepariwisataan. Diindonesiakan oleh Frans Gromang dari buku Tourism Management, Jakarta: Pradnya Paramita. 